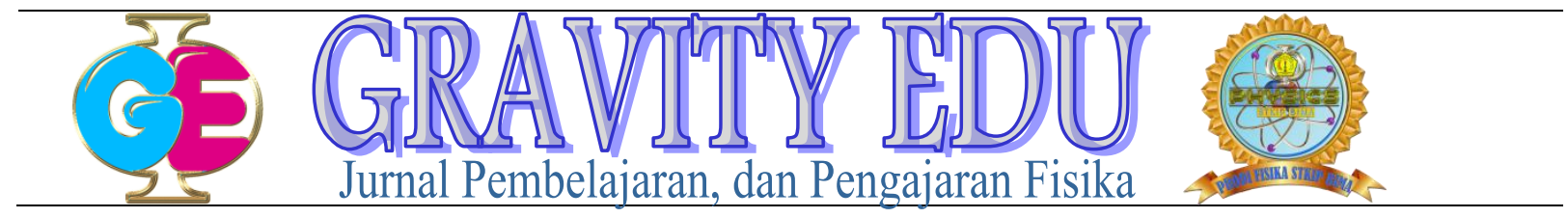

\title{
Pengembangan Modul Berbasis Discovery Learning Materi Momentum Dan Impuls
}

\author{
Baiq Azmi Sukroyanti. \\ Program Studi Pendidikan Fisika, FSTT UNDIKMA, \\ Jl. Pemuda No. 59 A, Mataram, Indonesia 83125 \\ e-mail: bqazmi@ikipmataram.ac.id
}

\begin{abstract}
ABSTRAK : Penelitian ini bertujuan untuk mengetahui kriteria kelayakan modul berbasis discovery learning pada mata pelajaran fisika untuk SMA kelas X. Penelitian ini menggunakan metode penelitian pengembangan (Research and Development). Model pengembangan yang digunakan dalam penelitian ini adalah model pengembangan ADDIE. Dalam penelitian ini hanya menggunakan tiga tahap yaitu analisi, desain, dan pengembangan. Instrumen yang digunakan adalah angket validasi ahli. Hasil yang di peroleh masing-masing skor pada validator ahli yang memiliki nilai berbeda-beda diantaranya, presentasi validator 1, 98,76\% dengan kategori sangat baik atau sangat layak digunakan, validator 2, dengan presentasi 81,48\% dengan kategori baik atau layak digunakan, validator 3 dengan presentasi 70,37\% dengan kategori baik atau layak digunakan, dan presentasi validator 4, 88,88\% dengan kategori sangat baik atau layak digunakan. Jadi dapat disimpulkan produk atau modul yang dikembangkan layak digunakan pada jenjang SMA khususnya pada mata pelajaran fisika kelas X SMA
\end{abstract}

\section{Kata kunci: Modul berbasis Discovery Learning}

\section{ABSTRACT}

This study aims to determine the eligibility criteria for discovery learning based modules in physics for grade $\mathrm{X}$ high school students. This study uses a (research and development method). The development model used in this research is the ADDIE development model. In this study, only three stages were used, namely analysis, design and development. The instrument used was an expert validation questionnaire. The results obtained by each score on expert validators who have different values include, validator presentation $1,98.76 \%$ in the very good or very suitable category, validator 2 , with a presentation of $81.48 \%$ in the good or feasible category. used, validator 3 with a presentation of $70.37 \%$ in the category of good or suitable for use, and the presentation of validator $4,88.88 \%$ with the category very good or fit for use. So it can be concluded that the product or module developed is suitable for use at the high school level, especially in the physics subject for class X SMA

\section{PENDAHULUAN}

Sains merupakan kumpulan ilmu-ilmu yang terdiri dari biologi, fisika, kimia, geologi dan astronomi yang berupaya menjelaskan setiap fenomena yang terdiri di alam [1]. Fisika merupakan salah satu cabang dari sains yang bukan hanya terdiri atas fakta, konsep dan prinsip saja, tetapi merupakan suatu penemuan. Pembelajaran fisika harus diarahkan untuk mencari tahu sehingga dapat membantu peserta didik untuk memperoleh penguasaan yang lebih mendalam. Pemebelajaran harus menekankan pada pemberian pengalaman langsung dan berpusat pada peserta didik [2]. Peserta didik akan lebih menguasai konsep jika konsep yang dipelajari dikaitkan dengan kehidupan sehari-hari dan peserta didik terlibat langsung dalam melakuakan sutau kegiatan dan akan selalu tertanam dalam pikiranya.

Fisika pada dasarnya adalah pembelajaran yang sangat menarik dan menyenangkan. Hal ini dikarenakan banyaknya konsep fisika yang berhubungan dengan kehidupan sehari-hari. Namun, kenyataannya banyak yang menganggap bahwa fisika adalah salah satu pembelajaran yang sangat sulit karena terdiri atas rumus dan angka, sehingga peserta didik merasa kesulitan mengkaitkan materi yang dipelajari dengan kehidupan sehari- hari.

Modul adalah buku yang ditulis dengan tujuan agar peserta didik dapat belajar secara mandiri tampa bimbingan guru, sehingga modul berisi paling tidak tentang segala komponen dasar bahan ajar yang telah disebutkan sebelumnya. Dengan demikian maka modul harus menggambarkan kompetensi dasar yang akan dicapai oleh siswa, disajikan dengan menggunakan bahasa yang baik, menarik, dilengkapi dengan ilustrasi. Menurut (Purwanto ddk, 2007) fungsi modul ialah sebagai bahan ajar yang digunakan dalam kegiatan pembelajaran siswa [3]. Dengan modul peserta didik dapat belajar lebih terarah dan sistematis. Modul juga diharapkan memberikan 
petunjuk belajar bagi peserta didik selama mengikuti pembelajaran.

Model pembelajaran penemuan atau discovery learning dapat membantu siswa menghilangkan keraguan keraguannya akan sebuah konsep karena mengarah pada kebenaran yang final dan pasti. Menurut Purwanto (2012) menunjukkan bahwa penerapan model pembelajarn discovery learning dapat meningkatkan kemampuan berpikir kritis siswa [4]. Hal tersebut juga sesuai dengan hasil penelitian Pratiwi (2014) yang menunjukkan bahwa peningkat keterampilan berpikir kritis siswa lebih tinggi menggunakan metode discovery learning dari pada menggunakan metode pembelajaran yang lain.

1. Modul

Menurut (Purwanto ddk, 2007) Modul adalah buku yang ditulis dengan tujuan agar peserta didik dapat belajar secara mandiri tanpa bimbingan guru, sehingga modul berisi paling tidak tentang segala komponen dasar bahan ajar yang telah disebutkan sebelumnya. Dengan demikian maka modul harus menggambarkan kompetensi dasar yang akan dicapai oleh siswa, disajikan dengan menggunakan bahasa yang baik, menarik, dilengkapi dengan ilustrasi. Fungsi modul ialah sebagai bahan ajar yang digunakan dalam kegiatan pembelajaran peserta didik. Dengan modul peserta didik dapat belajar lebih terarah dan sistematis dan modul juga diharapkan memberikan petunjuk belajar bagi peserta didik selama mengikuti pembelajaran.

2. Model Discovery Learning

Menurut Hosnan (dalam Juliani et al., 2017) Discovery Learning adalah salah satu model untuk mengembangkan cara belajar peserta didik aktif menemukan sendiri, menyelidiki sendiri, makan hasil yang diperoleh akan setia dan tahan lama dalam ingatan, tidak akan mudah dilupakan oleh peserta didik. Discovery Learning merupakan metode pembelajaran kognitif yang menuntut guru lebih kreatif menciptakan situasi yang dapat membuat peserta didik belajar aktif menemukan pengetahuan sendiri.

\section{METODE PENELITIAN}

Penelitian ini merupakan penelitian pengembangan. Metode penelitian ini atau Research and Develoment (R\&D) adalah metode penelitian untuk menembangkan produk atau menyempurnakan produk. Metode penelitian didefinisikan sebagai suatu metode penelitian yang digunakan untuk menghasilkan produk tertentu, dan menguji keefektifan produk tersebut [5].
Salah satu media yang memperhatikan tahap dasar pengembangan media yang sederhana dan mudah dipahami adalah kerangka ADDIE. ADDIE merupakan aktivitas pembelajaran yang memiliki karakter interaksi dengan beberapa langkah dasar, pembelajaran yang efisien, dinamis dan efektif. ADDIE merupakan singkatan yang mengacu pada proses utama dari proses pengembangan sistem pembelajaran yaitu: analisis kebutuhan, design, pengembangan, implementasi dan evaluasi [6]. Tetapi Pada tahap pengembangan ini digunakan hanya tiga fase yaitu: analis, desain dan pengembangan.

\section{Teknik Pengumpulan Data}

Teknik pengumpulan data adalah cara yang digunakan untuk mengumpulkan data. Metode pengumpulan data adalah cara-cara yang dapat dilakukan untuk mengumpulkan data. Pengumpulan data bertujuan untuk memperoleh data-data yang relevan, akurat, dan sesuai dengan tujuan penelitian [7]. Teknik pengumpulan data yang digunakan dalam penelitian ini adalah sebagai berikut:

\section{Lembar Validasi dan validator}

Lembar Validasi dalam penelitian ini digunakan untuk memperoleh masukan berupa kritik, saran, dan tanggapan terhadap modul berbasis Discovery Learning yang dikembangkan. Untuk mengetahui kevalidan modul dan instrument yang disusun, lembar validasi diberikan kepada validator, validator memberikan penilaian terhadap modul dengan memberi tanda centang pada baris dan kolom yang sesuai, menulis butir-butir revisi jika terdapat kekurangan pada bagian saran atau dapat menulis langsung pada naskah modul berbasis Discovery Learning.

Validasi modul dilakukan oleh empat validator yaitu dua orang ahli bidang media dan dua orang ahli bidang fisika. Lembar validasi yang diamati dalam penilaian berupa lembar validasi modul. Penilaian validator terhadap modul terdiri dari 4 kategori yaitu tidak valid (1), cukup valid (2), valid (3), dan sangat valid (4).

2. Teknik Analisis Data

Teknik analisis data pada penelitian ini berupa data deskriptif untuk mendapat angka rata-rata persentase. Teknik analisis data untuk validasi modul berbasis discovery learning sebagai berikut:

Analisis data yang diperoleh dari angket uji validasi para ahli digunakan untuk mengetahui kelayakan terhadap modul yang dibuat. Angket yang digunakan dalam penelitian ini adalah skala likert yang berperingkat 1-4 digunakan untuk memperoleh pendapat dari validasi para ahli dengan kriteria "Sangat Layak (SL), Layak (L), Tidak Layak (TL), dan Sangat 
Tidak Layak (STL)". Skor setiap alternatif jawaban yang diberikan oleh responden pada pernyataan Tabel sebagai berikut:

Mengubah skor rata-rata yang diperoleh menjadi nilai dengan kriteria. Hal tersebut dilakukan untuk mengetahui kualitas modul berbasis discovery learning hasil pengembangan yang mula-mula berupa skor di ubah menjadi data kualitatif. Dengan rumus persentase sebagai berikut:

$\%$ kelayakan $=\frac{\text { Rata }- \text { rata } \text { keseluruhan aspek }}{\text { skala tertinggi penilaian }} \times 100$

\section{HASIL DAN PEMBAHASAN}

Pengembangan modul berbasis Dircovery Learning menggunakan metode ADDIE. Model EDDIE terdiri dari lima tahap, yaitu Analisys, Design, Development, Inpelementation dan Evaluation. Tetapi pada tahap pengembangan ini, peneliti hanya menggunakan tiga tahap pengembangan yaitu analisis, perancangan, dan pengembangan dikarenakan keterbatasan waktu yang tidak memungkinkan untuk mengembangkan lima tahap.

Untuk memperoleh modul yang memenuhi layak/valid, peneliti mengikuti prosedur pengembangan dan menganalisis hasil penelitian untuk memenuhi tujuan tersebut, peneliti melakukan pengembangan modul berbasis discovery learning.

Langkah selanjutnya adalah Design (rancangan). Desain modul ini diawali dengan rancangan konsep modul berbasis Discovery Learning, yaitu memilih pendekatan pembelajaran yang digunakan dalam modul. Setelah merancang konsep, peneliti mempersiapkan referensi pendukung pembuatan modul. Referensi terdiri atas bukubuku fisika. Kemudian menentukan indikator dari KI dan KD yang sesuai dengan kurikulum 2013.

Tahap ketiga yaitu Development (pengembangan). Pada tahap ini diawali dengan penyusunan draf buku yang akan menjadi acuan dalam mengembangkan modul berbasis Discovery Learning. Komponen-komponen di dalam modul terdiri dari sampul modul, kata pengantar, daftar isi, petunjuk penggunaan modul, peta konsep, materi, lembar kerja siswa, soal evaluasi, daftar pustaka, dan glosarium. Modul yang dikembangkan yaitu berbasis Discovery Learning yang sesuai dengan materi yang dibahas.

Pada tahap ini, produk yang dikembangkan adalah berupa modul berbasis discovery learning materi pembelajaran fisika kelas X semester II. Selain itu peneliti juga mengembangkan penilaian-penilaian lain yang dijadikan suatu acuan dari semua perangkat pembelajaran yang dikatakan layak atau tidak layak untuk diterapkan dalam proses pembelajaran di sekolah. Data hasil validasi produk memaparkan tentang hasil tanggapan/kelayakan terhadap modul yang dikembangkan peneliti dari validasi ahli materi dan media. Berikut disajikan hasil data yang didapatkan dari keempat validator sebagai berikut.

Tabel 4.1 Data KualitaHasil Uji Kelayakuan Validasi Ahli

\begin{tabular}{lcll}
\hline Validator & $\begin{array}{l}\text { Skor Perolehan Kualifikasi } \\
(\%)\end{array}$ & Kriteria \\
\hline Validator 1 & $98,76 \%$ & Sangat Layak & Tidakperlurevisi/valid \\
Validator 2 & $81,48 \%$ & Sangat Layak & Tida perlu revisi/valid \\
Validator 3 & $70,37 \%$ & Layak & Tida perlu revisi/valid \\
Validator 4 & $88,88 \%$ & Sangat Layak & Tida perlu revisi/valid \\
\hline
\end{tabular}

Berdasarkan penilaian modul berbasis Discovery Learning yang dikembangkan peneliti modul tersebut layak digunakan atau sesuia. Hal ini terbukti dari hasil yang didapatkan dari validator ahli. Dari keemptat validator tersebut dapat disimpulkan bahwa modul berbasis Discovery Learning sangat layak digunakan berbagai jenjang SMA/MA.

\section{KESIMPULAN}

Bedasarkan hasil penelitian dan pengembangan yang dilakukan peneliti, maka dapat diambil kesimpulan sebagai berikut:

1. Modul yang dikembangkan peneliti termasuk dalam kategori sangat layak diterapkan sebagai panduan belajar. Modul berbasis discovery learning perlu dikembangkan lagi pada materi lain selain Momentum dan Impuls yang sesuai dengan komponen-komponen yang terdapat pada perangkat.

2. Bedasarkan penilain dari validator, modul berbasis discovery learning dinyatakan valid oleh validator 1 dengan persentase $98,76 \%$ (sangat layak), validator 2 dengan presentase $81,48 \%$ (sangat layak), validator 3 dengan presentase $70,37 \%$ (layak) dan validator 4 dengan presentase $88,88 \%$ (sangat layak). Dengan demikian hasil penelitian yang menunjukkan bahwa modul berbasis discovery learning berkualifikasi baik dan tidak perlu revisi.

\section{DAFTAR PUSTAKA}

[1] Gunawan. 2015. Model Pembelajaran Sains Berbasis ICT. Mataram: FKIP UNRAM.

[2] Yeritia, S., Wahyudi \& Rahayu, S. 2017. Pengaruh model pembelajaran inkuiri terbimbing terhadap penguasaan konsep dan kemampuan berpikir kritis fisika peserta didik kelas X SMAN 1 Kuripan tahun ajaran 2017/2018.Jurnal Pendidikan Fisika dan Teknologi.3(2), 181-187. 
[3] Purwanto.(2007). Pengembangan modul.Pusat Teknologi Informasi dan Komunikasi, Depdiknas, Jakarta.http://issuu.com/download-

bse/docs/buku_pengembangan_modul_full. diakses $: 16$ September 2013.

[4] Purwanto. (2012). Metodelogi Penelitian Kuantitatif untuk Psikologi dan Pendidikan. Yogyakarta : Pustaka Pelajar Offset.

[5] Sugiyono (2017). Metode Penelitian Kuantitatif, Kualitatif, dan $R \& D$. bandung : Alfabeta. CV

[6] Branch, R.M. 2009. Instructional Desain : The ADDIE Approach. London: Springer Science 